\title{
Coffee and cocoa dissemination through information and communication technology (ICT) during the Covid-19 pandemic
}

\author{
Alvin Rizki Ramadhani*, Diany Faila Sophia Hartatri, and Sholahuddin Akbar \\ Indonesia Coffee and Cocoa Research Insititue, PB Sudirman 90 Jember, Indonesia
}

\begin{abstract}
Digital transformation and COVID-19 pandemics have changed human behaviour in their interactions. Virtual communication has become a new behaviour in this era. Indonesia Coffee and Cocoa Research Institute (ICCRI) held Puslitkoka Webinar Series as part of digital transformation in the dissemination. This research discusses the effectiveness of virtual learning through webinars for disseminating coffee and cocoa innovation and technologies. This research applied a purposive method to the participants of the Puslitkoka Webinar Series. Data collection was conducted from February until May 2021 by a survey with 241 respondents. The research result showed that: 1) expectation attribute was $87.82 \%$, meaning met their expectation, 2) the satisfaction attribute was very good $(90.79 \%), 3)$ the attributes of the participants' desire to take part in the next webinar is great desire $(93.03 \%), 4)$ participants were very eagerly $(87.88 \%)$ to share webinar to their colleagues, 5) participants were very eagerly $(91.12 \%)$ to recommend the webinar to their colleagues, 6) participants were very interested $(90.46 \%)$ in participating in technology dissemination activities through webinars, and 7) participants' interest in technology dissemination directly (face-to-face) was lower than interest in webinars, but was still very interested $(83.65 \%)$. Puslitkoka Webinar Series as a hub of coffee and cocoa dissemination.
\end{abstract}

\section{Introduction}

Coffee and cocoa are important commodities in Indonesia. Smallholder farmers cultivate more than $90 \%$ of coffee and cocoa estates. It means about 2 million farmer's household economy is dependent on these commodities. Coffee and cocoa are expected to become commodities that support the community's economy, especially farmers, and support the national economy as a provider of employment and a source of foreign exchange.

Indonesia is known as a producer and exporter of coffee in the world. The average coffee production from 2014-2018 was 662.75 thousand tons per year, the fourth largest after Brazil, Vietnam, and Colombia. Indonesia's coffee exports, on average from 2013-2017 was 462.61 thousand tons per year, the fourth coffee exporter in the world after Brazil, Vietnam, and Colombia. $95.45 \%$ of Indonesian coffee is cultivated on people's plantations, while large private plantations cultivate the rest by $2.44 \%$ and large state-owned plantations by $2.21 \%$.

* Corresponding author: ramadhani.alvinrizki@iccri.net 
Robusta coffee production centres in Indonesia are South Sumatra, Lampung, Bengkulu, East Java and Central Java. Arabica production centres are Aceh, North Sumatra, South Sulawesi and West Sumatra [1]

The area of cocoa plantations in 1997 was recorded at 0.53 million ha, and in 2018 it became 1.61 million ha, an increase of 204\%. Currently, cocoa plantations are mostly managed by People's Plantations (98.33\%), 0.77\% are managed by large state-owned plantations and the remaining $0.90 \%$ are large private plantations. The main cocoa production centres in the last 5 years are Central Sulawesi, South Sulawesi, Southeast Sulawesi, West Sumatra, West Sulawesi, Lampung and Aceh [2].

One of the activities of the Indonesian Coffee and Cocoa Research Institute (ICCRI) is technology dissemination. Coffee and cocoa production centres are the main target areas in technology dissemination. Technology dissemination is an activity to disseminate information about technology and innovations that have been made by ICCRI, starting from the upstream to the downstream of coffee and cocoa commodities. ICCRI's mission is to increase the adoption of the latest technologies and innovations by all coffee and cocoa stakeholders, from farmers, processors, traders, government, industry, associations, and others. Under normal situations, technology dissemination was carried out by direct meetings like "Temu Lapang Kopi" and "Temu Lapang Kakao", direct assistance to regions, training both at the ICCRI Training Centre and in the regions. Due to the COVID-19 pandemic, this activity cannot be carried out.

However, technology dissemination must be continued to increase the adoption of innovation for stakeholders in coffee and cocoa commodities. The production and quality of coffee and cocoa must be maintained as part of food security and the economy of coffee and cocoa farmers. The alternative to still being able to disseminate technology and communicate with all coffee and cocoa stakeholders is to hold a virtual dissemination event

In Indonesia, COVID-19 was detected for the first time in March 2020. After that, the government tries to made policy to press COVID-19 pandemics. The Indonesian Government published a health protocol policy to organize the people not to get infected by COVID-19. One of the health protocols is social distancing. The social distancing policy for COVID-19 made people unable to interact like usual. The government urges people to keep their distance among us, not to travel if it is not very important, or use information technology to meet or hold an event.

Dissemination is still the spearhead of technology transfer in agriculture and socialization at the farmer level. However, various kinds of extension problems, such as limited human resources and the quality and supporting facilities, can become obstacles in achieving the success of extension. The Covid-19 pandemic has made the counselling process even more difficult. The utilization of ICT is a tool that can help extension workers in carrying out their duties during the Covid-19 pandemic [3].

The problems of extension in the era of the Covid-19 pandemic are: (1) the low level of cosmopolitan farmers makes the information obtained is slow; (2) farmers with all their limitations find it difficult to adapt to changes; (3) the radius of farmer's trust is very short. Thus, the challenges of extension in the future are: (1) how to generate an entrepreneurial spirit for farmers; (2) introduction of social media and web applications is a must as new media that extension workers must use, and (3) future counselling must be able to synergize conflicts of interest between stakeholders [4]. Agricultural Extension professionals play a critical role in outreach and translation of research to practice [5].

Digital transformation and Covid-19 pandemics have changed human behaviour in their interactions. Virtual communication has become a new behaviour in this era. This research discussed the effectiveness of virtual learning through webinars to disseminate coffee and cocoa technologies. 


\section{Methods}

This research design used a mixed-method between quantitative and qualitative methods. This research method combines quantitative and qualitative methods to be used in research activity to obtain more comprehensive, valid, reliable, and objective data [6].

The sampling method used in this study was non-probability sampling. Non-probability sampling is a sampling method that does not allow each element or member of the population to be selected as a sample. The sampling method used in this research was purposive sampling. Purposive sampling is a sampling method of data sources with certain considerations [6]. In this study, the concerns taken into the sample were participants who attended webinars until the final session in each webinar. Data collection was conducted from February until May 2021. There are 241 respondents within three times of the Puslitkoka Webinar Series.

Data collection was carried out using a questionnaire. The questionnaire is a data collection technique done by giving a set of written questions to respondents to answer [7]. Questionnaires were given to Puslitkoka Webinar Series participants who participated in the webinar until the end of the session. The data analysis used in this study was descriptive statistics, the statistics used to analyze data by describing or describing the data that has been collected as it was without intending to make conclusions that apply to the public or generalizations [6].

The measurement scale was a research instrument used to describe the survey results. The measurement scale used in this study was the Likert scale. The Likert scale measured a person's attitudes, opinions, and perceptions about social events or phenomena. Using a Likert scale, the variables to be measured were translated into dimensions, dimensions are translated into sub-variables, and sub-variables are translated into indicators that can be measured [8]. The measurement scale was intended to classify the perception of Puslitkoka Webinar Series' Participants to be measured. There were some attributes which measured in this research, namely the delivery of material, participants' expectations of the webinar, satisfaction with the webinar held, the desire to take part in the next webinar, telling the contents of the webinar to friends, recommending the Puslitkoka Webinar Series to friends, interest in online seminars, and interest in offline seminars (direct seminars).

\section{Result and discussion}

Scientific dissemination plays an important role in spreading scientific and technological information, provoking curiosity, dialogue, and interaction [9]. During the Covid-19 pandemic, the implementation of socialization activities has changed. Most of the mentoring methods have changed from using interpersonal communication (face-to-face) to using media (SMS, WhatsApp, telephone, zoom, and YouTube live streaming) or electronic media (broadcasting, TV) to communicate, and video media for farmers who do not have cell phones or internet access. The frequency of outreach activities has also decreased. Extension workers help farmers to have today's competitiveness, proactive competitiveness, and adaptability so that they are ready and able to adapt to changes during the Covid-19 pandemic[10]. If responsibly and appropriately used, social media has the potential to provide rapid and effective dissemination routes for key information [11].

The results also show that the guidance provided by agricultural extension workers to farmers groups during the COVID-19 pandemic has changed. Changes occurred in the number of visits by agricultural instructors to the target, the number of training materials provided, and extension methods. External factors that affect the performance of extension services are facilities and infrastructure to support extension activities and environmental conditions in locations [12]. 
The communication strategy used is the individual face-to-face communication method and cellular telephone-mediated communication. Group meetings were cancelled, and farm visits and home visits became options. Although there is no group meeting, the application of recommended technology is still carried out correctly by farmers [13]. The results of the analysis show that the role of extension workers in carrying out extension activities during the COVID-19 pandemic is the role of extension workers as supporters of government program policies, motivators for farmers, and facilitators in supporting farming activities [14].

Puslitkoka Webinar Series is one of the dissemination activities as part of adapting the new normal during the COVID-19 pandemic. The webinar was held as a means to keep in touch with coffee and cocoa stakeholders in Indonesia. The webinar was held with topics that match the current conditions in coffee and cocoa plantations. At the beginning of the Puslitkoka Webinar Series, several things to consider were access and equipment available to participants. Worries about internet access that is not fast to interfere with smooth communication during the dissemination activities are not a problem.

In some areas, there are not enough internet facilities and infrastructure. Therefore, it is necessary to support the central and local governments in providing internet facilities and infrastructure for agricultural extension workers. The policies needed include increasing the socialization of various sources of information available on the internet, developing the competence of extension workers, especially skills in accessing information via the internet, providing quality information sources through the development of information materials following the needs of agricultural extension workers [15].

In the webinar, ICCRI became a speaker and bridge between stakeholders in coffee and cocoa commodities. The speakers in the webinar are researchers or Puslitkoka experts and invite practitioners who Puslitkoka has assisted. By asking outside parties who have become Puslitkoka's partners in technology dissemination, they can convince the public that the innovations and technology produced by Puslitkoka have impacted the coffee and cocoa community.

The role of ICT in Agriculture plays a new modern paradigm that facilitates and improves the agricultural sector. The ICT had rendered service to farmers for market access, the announcement of weather conditions, awareness of crop diseases, etc. Several types of ICT tools are used in the agriculture sector, such as radio, television, mobile phones, internet, electronic money transfer, etc. The ICT helps the farmers to understand the gap between productivity and market demand [16].

Digital agriculture can help to offer a wide range of support to address the impacts of COVID-19 on agricultural production, labour availability, input supply, and logistics. Thus, effective communication and decision-making systems must be strengthened immediately, and extension personnel can help in this regard to save the agriculture sector from the obvious impact of COVID- 19 [17].

\subsection{Characteristic of Puslitkoka webinar series participants}

Respondents in this study were Puslitkoka webinar series participants. Participants who became respondents follow the activities until the end of the session in each webinar. It is important because we want to know the perceptions of participants who fully participate in the webinar. The following are the characteristics of Puslitkoka Webinar Series participants for three webinars that took place from February - May 2021. 


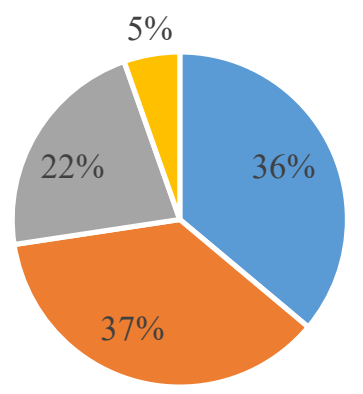

- Generation Z

- Millenials

- Generation X

Baby Boomer

Fig. 1. Generation of The Puslitkoka Webinar Series's Participant

Based on Figure 1, it can be seen that millennials mostly follow the participants in the webinar as a means of technology dissemination at $37 \%$ and Generation $Z$ by $36 \%$. Meanwhile, generation X and baby boomers are $22 \%$ and $5 \%$, respectively. Baby boomers are the generation born from 1946 - 1964. Generation X is the generation born from $1965-$ 1980. Millennials are born from 1981 - 1994, and Generation Z is born from 1995 - 2010. The dissemination of technology using webinars is mostly followed by Millennials and Generation Z. With this generation receiving information on coffee and cocoa innovation and technology. It is hoped that they will be able to adopt innovations and technology better. This generation represents the younger generation who will become the next generation in coffee and cocoa commodities.

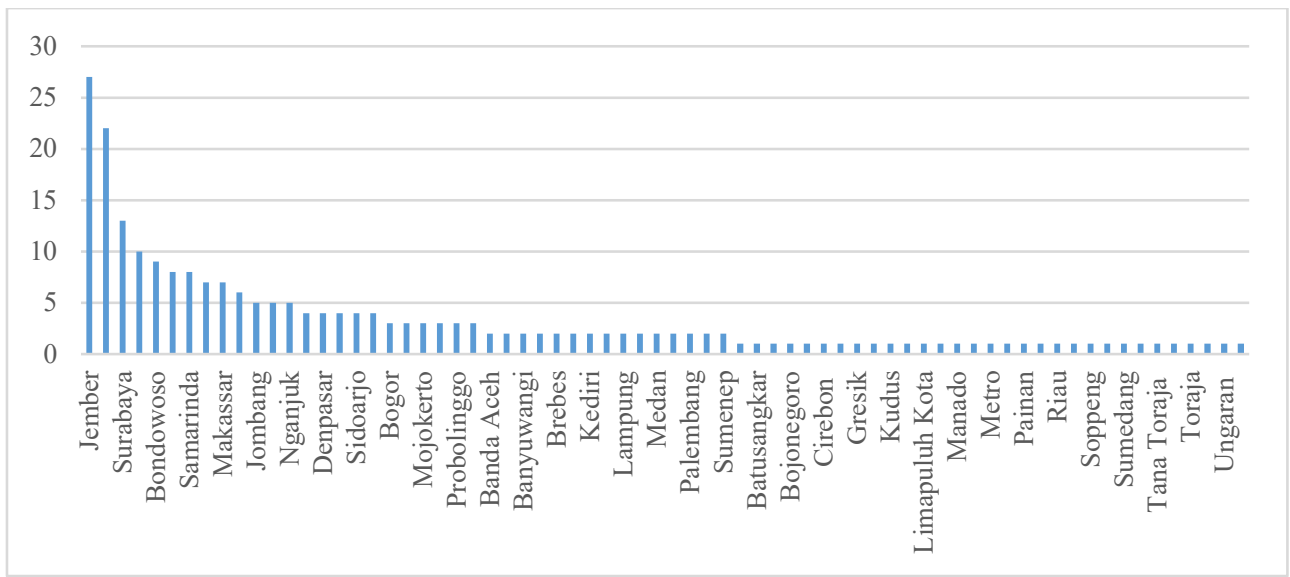

Fig. 2. Location of Puslitkoka Webinar Series Participant

The main target locations for ICCRI technology dissemination are South Sumatra, Lampung, Bengkulu, East Java, and Central Java, Aceh, North Sumatra, South Sulawesi, and West Sumatra for coffee. For Cocoa, the location target is Central Sulawesi, South Sulawesi, Southeast Sulawesi, West Sumatra, West Sulawesi, Lampung and Aceh. Based on the graph above, it can be seen that most of the participants in the webinar are generally located on the island of Java. Only a small proportion are located outside of Java. Areas that are the target of the dissemination of coffee and cocoa technology are not evenly distributed in all production centre. It is possible because information technology infrastructure outside Java is still not accessible to coffee and cocoa stakeholders, especially coffee farmers or cocoa farmers outside Java. 
Transport availability proved to be the major stumbling block during lockdowns. This was worsened by curfews and stringent penalty measures for those who breached the law on COVID-19 control. In many cases, extension workers were unable to move around and reach out to farmers for agricultural advice. The use of social media was viewed as the most preferred means of communication during national lockdowns. However, data and network coverage costs may leave some farmers out due to natural geographic distribution differences. There is a need for telecommunication companies to reasonably cut data charges and put infrastructure to cover the remaining unreachable areas. [18]. It also referred to a study that implied ICT's role in agriculture encountered the problem faced by the farmers to access ICT. The high cost of ICTs tool was the main constraint for the farmers [19].

\subsection{Perception of Puslitkoka webinar series participants}

Several attributes are of concern in this study, namely the delivery of material, participants' expectations of the webinar, satisfaction with the webinar held, the desire to take part in the next webinar, telling the contents of the webinar to friends, recommending the Puslitkoka Webinar Series to friends, interest in online seminars, and interest in offline seminars (direct seminars). On the attributes of the delivery of the webinar material, participants stated that they received the webinar material very well, or $90.2 \%$. Submission of material is the main thing in the webinar because that is the core of the technology seminar. Information materials regarding information and technology can be conveyed properly to the participants so that the message to be shared by ICCRI can be received.

On the attribute of the suitability of the material to their expectations, participants stated that their expectations were met by $87.72 \%$, which means that their expectations were in accordance with what ICCRI conveyed in the webinar. This shows that the material presented by ICCRI in disseminating this technology is still needed by coffee and cocoa stakeholders. On the attribute of participant satisfaction with the course of the webinar, participants stated that they were satisfied with the implementation of the webinar so that it became interesting for ICCRI that the performance of the webinar could still be carried out so that technology dissemination activities during the pandemic could still run even though in a different way.

Participants stated that they were very satisfied (90.79\%) with the webinar held on the satisfaction attribute. This shows that the community has well received the management of the Puslitkoka Webinar Series team. ICCRI, as the organizer, will be very happy to receive advice and suggestions for improvement in the future. The next attribute also supports participant satisfaction, i.e. participants expressed a great desire $(93.03 \%)$ to take part in the next webinar, participants also very eagerly $(87.88 \%)$ to share the Puslitkoka Webinar Series with their colleagues, and participants also very eagerly $(91.12 \%)$ to recommend the Puslitkoka Webinar Series to their colleagues.

On the attribute of interest in participating in dissemination activities through webinars, participants stated they were very interested $(90.46 \%)$ in participating in technology dissemination activities through webinars. On the other hand, participants' interest in technology dissemination directly (face-to-face) was lower than participants' interest in webinars. However, participants were still very interested $(83.65 \%)$ in participating in technology dissemination activities directly. This shows that coffee and cocoa technology dissemination is still in great demand by coffee and cocoa stakeholders. This is good for increasing the adoption of the latest innovations and technologies in coffee and cocoa.

With good perceptions from all participants in the Puslitkoka Webinar Series, this shows that the wider community can accept changes that occur in the way technology dissemination. Although in practice, sometimes there are problems with the devices used for on-air or on the internet connection. But these obstacles do not become a barrier to the implementation of technology dissemination activities by utilizing ICT. This is in line with what Verma and 
Singh stated: transition in students' learning habits and trends is evident from the traditional text based on the current dynamic modes like world-wide-web, CAI, and simulation. Webinar as a learning technology offers a platform to overcome the gap in this digital divide and help the students get acquainted with the latest. Webinar today has gained significant popularity. More and more institutions want to leverage technology in education and percolate its maximum advantage to their students. It has helped overcome the issues of bandwidth and leverage expertise but has still developed its potential as an interactive forum and costeffectiveness. This technology can be deployed to harness a formal mechanism of measurement and an evaluation framework. Its usage can be extended to other areas of learning and its target audience base increased [19]. ICTs play a significant role in enhancing agricultural production. The study is envisaged to play a greater role in using the ICTs in farming, optimizing the uses of ICT tools, and filling the gap [20].

\section{Conclusions}

Technology dissemination activities by utilizing ICT can be an alternative in disseminating during the COVID-19 pandemic and in the future. Dissemination through webinars can continue to be carried out to increase public access to information on the latest innovations and technologies, especially on coffee and cocoa commodities. Millennials and Generation $\mathrm{Z}$ participated in this technology dissemination activity. The implementation of technology dissemination through webinars has not yet reached all coffee and cocoa production centres, so there is a need for increased promotion or internet access in areas outside Java. The participant's perspective on implementing technology dissemination through webinars is very good, so this can continue to be implemented.

\section{References}

1. Kementrian Pertanian Republik Indonesia. Outlook Komoditas Perkebuan Kopi. (Pusat Data dan Sistem Informasi Pertanian Sekretariat Jenderal - Kementerian Pertanian RI, 2020)

2. Kementrian Pertanian Republik Indonesia. Outlook Komoditas Perkebunan Kakao. (Pusat Data dan Sistem Informasi Pertanian Sekretariat Jenderal - Kementerian Pertanian RI, 2020)

3. A.M. Ar-rozi, K.S. Indraningsih, Sunarsih. Optimalisasi Pemanfaatan Teknologi Informasi Dan Komunikasi Untuk Penyuluhan Pertanian Pada Masa Pandemi Covid-19. in Dampak Pandemi Covid-19 Perspektif Adaptasi dan Resiliensi Sosial Ekonomi Pertanian 635-654 (IAARD Press, Jakarta, 2020)

4. A. Wibowo. Prosiding Seminar Nasional Fakultas Pertanian UNS, 4 (2020)

5. S. Sampson, J. Mazur, G. Israel, S. Galindo, C. Ward. Journal of Agromedicine, 25 (2020)

6. Sugiyono. Metode Penelitian dan Pengembangan (Research and Development/ $R \& D)$. Alfabeta (2019)

7. Sugiyono. Metode Analisis Kuantitatif. (Alfabeta, 2019)

8. Riduwan, Sunarto. Pengantar Statistika untuk Penelitian: Pendidikan, Sosial, Komunikasi, Ekonomi, dan Bisnis. (Alfabeta, 2019)

9. A.T.S. Ferreira, et al. Creat. Educ., 12 (2012)

10. K.S. Indraningsih, K.S. Septanti. Penyuluhan Pertanian dalam Upaya Pemberdayaan Petani Pada Era Pandemi Covid-19. (Pusat Sosial Ekonomi dan Kebijakan Pertanian, Bogor, 2020)

11. A.K. Chan, C.P. Nickson, J. Rudolph, G. Joynt. Anaesthesia, 75 (2020) 
12. H.T. Wibowo, Y. Haryanto. Jurnal Penelitian Peternakan Terpadu, 2 (2020)

13. I.W. Suadnya, A.P. Hadi, E.P. Paramita. Prosiding SAINTEK, 3 (2021)

14. Sudarmansyah et al. Jurnal AGRIBIS, 14 (2021)

15. E. Kustanti, A. Rusmana, P. Hadisiwi. J Penelit. dan Pengemb. Pertan. 39 (2020)

16. J.D.A. Dhakshana, K.V.R.E. Rajandran. Int. J. Supply Chain Manag. 7 (2018)

17. R. Chatterjee. Food Sci. Reports 1 (2020)

18. M.P. Bright, N.T. Kudzai, C. Ngavaite. Cogent Food Agric., 7 (2021)

19. A. Verma, A. Singh. J. Emerg. Technol. Web Intell., 2 (2010)

20. S. Das, M.N. Munshi, W. Kabir. SAARC J. Agric., 14 (2017) 